\title{
WPROWADZENIE
}

Klio. Czasopismo poświęcone dziejom Polski i powszechnym PL ISSN 1643-8191, t. 47 (4)/2018, s. 3-8

(1) $\odot$

\author{
HanNa ApPeL \\ KAROL KŁODZIŃSKI"
}

\section{Władza i urzędnicy w starożytnym Rzymie Uwagi wstępne}

Z agadnienia z ustroju starożytnego Rzymu epoki Republiki i Wczesnego Cesarstwa, szerzej zaś z zakresu rzymskiego prawa publicznego, obecnie cieszą się sporym zainteresowaniem zarówno wśród polskich historyków starożytności ${ }^{1}$, jak i romanistów ${ }^{2}$. W Polsce tego rodzaju badania

* Uniwersytet Mikołaja Kopernika, Wydział Nauk Historycznych, ul. Bojarskiego 1, 87-100 Toruń, hanna.appel@umk.pl; ORCID:0000-0002-0342-3469.

** Uniwersytet Mikołaja Kopernika, Biblioteka Uniwersytecka, ul. Gagarina 13, 87-100 Toruń, kklo@umk.pl, cezar871@wp.pl; ORCID: 0000-0002-4625-2874.

${ }^{1}$ Pozostając tylko przy opracowaniach monograficznych, które ukazały się w ostatnich latach, warto wymienić: H. Appel, Kontrowersje wokót Senatus Consultum Ultimum: studium z dziejów późnej republiki rzymskiej, Toruń 2013; S. Ruciński, Praefecti praetorio: dowódcy gwardii pretoriańskiej od 2 roku przed Chr. do 282 roku po Chr., Bydgoszcz 2013; D. Okoń, Senatorski cursus honorum w okresie republiki $i$ wczesnego cesarstwa: wybrane zagadnienia, Poznań 2016; P. Sawiński, Sukcesja wtadzy cesarskiej w okresie rządów dynastii julijsko-klaudyjskiej (30 p.n.e. - 68 n.e.), Poznań 2016; K. Kłodziński, Officium a rationibus. Studium z dziejów administracji rzymskiej w okresie pryncypatu, Toruń 2017.

2 Zob. M. Zabłocka, Rzut oka na polska romanistykę $w$ pierwszym dziesięcioleciu XXI wieku, „Zeszyty Prawnicze UKSW” 2012, t. 12, nr 1, s. 7-26; por. eadem, Romanistyka polska po II wojnie światowej, Warszawa 2002. 
korzeniami sięgają jeszcze końca XIX wieku (studia autorstwa Teodora Dydyńskiego) ${ }^{3}$, lecz przez wiele lat, inaczej niż w Niemczech czy Francji, nie były prowadzone na szeroką skalę́ . Zapewne jedną z przyczyn tego stanu rzeczy jest fakt, że monumentalne dzieło Römisches Staatsrecht Theodora Mommsena, inaczej niż Römische Geschichte ${ }^{5}$, nie zostało przetłumaczone na język polski ${ }^{6}$. Warto jednak podkreślić, że powojenne badania nad funkcjonowaniem rzymskiej administracji prowincjonalnej, wspólnot lokalnych, elit municypalnych czy instytucji religijnych utworzyły swego rodzaju osobny nurt w polskiej historiografii starożytniczej i położyły podwaliny pod dalsze badania ${ }^{7}$. Współcześni badacze instytucji i administracji republikańskiego oraz cesarskiego Rzymu, choć odwołują się do dorobku swych poprzedników, starają się jednak podejmować kolejne obszary badawcze,

${ }^{3}$ K. Kłodziński, Wybrane dzieta Teodora Dydyńskiego jako przyktad prekursorskich badań nad rzymskim prawem publicznym w Polsce, "Czasopismo Prawno-Historyczne” 2012, t. 64, z. 2, s. 403-422.

${ }^{4}$ Prace Z. Zmigrydera-Konopki, J. Linderskiego, A. Krawczuka oraz T. Łoposzki są tu wyjątkiem. Zob. Z. Zmigryder-Konopka, Studja nad historja ustroju rzymskiego. Cz. 1, Warszawa 1936; J. Linderski, Państwo a kolegia: ze studiów nad historią rzymskich stowarzyszeń u schytku republiki, Kraków 1961; idem, Rzymskie zgromadzenia wyborcze od Sulli do Cezara, Wrocław 1966; A. Krawczuk, Virtutis ergo. Nadania obywatelstwa rzymskiego przez wodzów Republiki, Kraków 1963; T. Łoposzko, Trybunat Publiusza Klodiusza w świetle źródet i historiografii, Warszawa 1974.

${ }^{5}$ Zob. T. Mommsen, Historya rzymska, t. I-IV, przeł. T. Dziekoński, Warszawa 1880.

${ }^{6}$ C. Bruun postawił przekonującą tezę, że brak tłumaczenia Römisches Staatsrecht na język angielski skutkował tym, że angielscy uczeni, z kilkoma wyjątkami, rzadko podejmowali „constitutional issues in the Roman World”. W zakresie badań nad epoką Wczesnego Cesarstwa pewien przełom przyniosły dopiero prace Petera Brunta i Fergusa Millara. Zob. C. Bruun, Roman Government and Administration, [w:] The Oxford Handbook of Roman Epigraphy, red. C. Bruun, J. Edmondson, Oxford 2015, s. 275.

7 J. Kolendo, Kolonat w Afryce rzymskiej w I-II wieku i jego geneza, Warszawa 1962; T. Kotula, Zgromadzenia prowincjonalne w rzymskiej Afryce w epoce późnego cesarstwa, Wrocław 1965; M. Jaczynowska, Collegia Iuvenum. Rola historyczna i dziatalność organizacji mtodzieży rzymskiej w okresie Wczesnego Cesarstwa, Toruń 1964; S. Mrozek, Stosunki spoteczne w rzymskich kopalniach ztota w Dacji w II wieku naszej ery / Mines d'or de Dacie au IIe siècle (aspects sociales et administratives), Toruń 1966; L. Mrozewicz, Arystokracja municypalna w rzymskich prowincjach nad Renem i Dunajem w okresie Wczesnego Cesarstwa, Poznań 1989. 
których tematyka oscyluje wokół kwestii związanych z władzą i urzędnikami w starożytnym Rzymie.

Temu zagadnieniu była też poświęcona konferencja pt. „Optimus Civis. Władza i urzędnicy w starożytnym Rzymie”, zorganizowana przez Zakład Historii Starożytnej IHiA (UMK), która odbyła się 1 czerwca 2018 roku. Jej tematyka dotyczyła m.in. kwestii wyborczych, administracyjnych, politycznych oraz religijnych związanych z karierą urzędniczą i sprawowaniem władzy.

Warto nadmienić, że problematyka badawcza dotycząca w jakimś stopniu karier urzędniczych oraz pewnych aspektów działań polityczno-administracyjnych w okresie Republiki była niejednokrotnie przedmiotem rozważań podejmowanych przez uczestników wcześniejszych konferencji starożytniczych, organizowanych przez Zakład Historii Starożytnej UMCS ${ }^{8}$ oraz Zakład Historii Starożytnej Instytutu Historii UŚ9. Podczas tych spotkań prelegenci skupiali się wszakże na możliwie wszechstronnym przedstawieniu wizerunku konferencyjnego bohatera, takiej czy innej wybitnej jednostki oraz jej bezpośredniego otoczenia ${ }^{10}$, natomiast kwestie ogólniejszej natury, powiązane z problematyką sprawowania władzy i funkcjonowania urzędników, stanowiły tło dla zasadniczych rozważań konferencyjnych.

Artykuły zebrane w prezentowanym tomie wpisują się we wspomniany nurt konferencyjnych dyskusji, ale ich autorzy, co zrozumiałe, podejmują inne wątki badawcze. I tak Tomasz Ładoń omawia karierę polityczną Lucjusza Korneliusza Sulli zamkniętą w latach dziewięćdziesiątych I wieku

${ }^{8}$ W kwietniu 2013 r. odbyła się konferencja pt. „Lucjusz Korneliusz Sulla - historia i tradycja”, a w grudniu 2014 r. „Marek Antoniusz - historia i tradycja”. Pokłosiem obu konferencji są publikacje: Lucius Cornelius Sulla - history and tradition, red. D. Słapek, I. Łuć, Lublin 2013 oraz Marcus Antonius - history and tradition, red. D. Słapek, I. Łuć, Lublin 2016.

9 W listopadzie 2015 r. odbyła się konferencja pt. „Gn. Pompejusz Wielki. Historia i tradycja”, a w listopadzie 2016 r. „Wybitni Rzymianie czasów schyłku Republiki. Gajusz Juliusz Cezar". Po konferencji poświęconej Pompejuszowi ukazała się monografia pt. Wybitni Rzymianie czasów schytku republiki. Gnejusz Pompejusz Wielki (106-48 przed Chrystusem), red. N. Rogosz, Katowice 2018.

10 Zob. D. Słapek, Biografistyczne doświadczenia starożytników (na marginesie konferencji „Marek Antoniusz - historia i tradycja” (Lublin 08-09.12.2014 r.), „Res Historica” 2014, t. 38, s. 253-264. 
p.n.e. Autor skupia się przede wszystkim na przedstawieniu wcześniejszej kariery urzędniczej przyszłego dyktatora. Rezygnacja Sulli ze startu w wyborach na edyla była przedstawiana jako powód późniejszej porażki, jaką poniósł on w wyborze na pretora miejskiego. Ładoń raz jeszcze poddaje interpretacji dostępne źródła, by określić polityczną rolę, jaką Sulla odgrywał w republice rzymskiej w początkach pierwszego stulecia. Jego zdaniem swoistym katalizatorem w rozwoju kariery politycznej Sulli stało się rozstanie z Mariuszem i zawarcie nowych sojuszy. Andrzej Gillmeister w swoim artykule próbuje dowieść tezy, że stanowisko flamen Dialis, którego objęcie wiązało się z zasiadaniem w senacie, mogło być innym sposobem na rozpoczęcie kariery patrycjusza, zwłaszcza wtedy, gdy pochodził on z gens minor. Hanna Appel w artykule poświęconym frekwencji wyborczej w późnorepublikańskim Rzymie podkreśla znaczenie tego problemu dla zrozumienia pojęcia i funkcjonowania „demokracji” w republikańskim Rzymie ${ }^{11}$. Współczesnych badaczy uczestnictwo obywateli uprawnionych do głosowania w wyborach interesuje przede wszystkim dlatego, że określony wybór polityków ma ogromne znaczenie dla życia całej społeczności. Jak się okazuje, zagadnienie wyborczej frekwencji w republikańskim Rzymie było postrzegane inaczej niż dzieje się to obecnie w krajach rozwiniętej demokracji, i zapewne dlatego w żadnym z dostępnych źródeł nie znajdujemy najmniejszej wzmianki na ten temat. Możemy domniemywać, że frekwencja wyborcza w Rzymie była niska, ale fakt ten nie stanowił problemu ani dla tych, którzy mieli zostać wybrani, ani dla ich wyborców. Michał Norbert Faszcza przedstawia swoje rozważania na temat kwestii uprawnień cenzorskich, które znacząco wpłynęły na utrzymanie dyscypliny w wojsku. Jak pokazuje, poprzez recognitio equitum i regimen morum cenzorzy mogli skutecz-

${ }^{11}$ Dyskusję na temat rzymskiej „demokracji” sprowokował w ostatnich latach ubiegłego wieku Fergus Millar serią artykułów. Zob. np. F. Millar, The Political Character of the Classical Roman Republic, "Journal of Roman Studies” 1984, t. 74, s. 1-19; idem, Politics, Persuasion and the People before the Social War (150-90 B.C.), "Journal of Roman Studies” 1986, t. 76, s. 1-11; idem, Political Power in Mid-Republican Rome: Curia or Comitium, „Journal of Roman Studies” 1989, t. 79, s. 138-150. Warto przy okazji zauważyć, że dyskusja na ten temat zachęciła wielu historyków do badań nad funkcjonowaniem systemu politycznego w Rzymie, tak że wielu z nich, zajmując się problemami republiki, uznało za stosowne wypowiedzieć się w tej kwestii. 
nie ingerować w sprawy armii. Małgorzata Pawlak, której zainteresowania badawcze koncentrują się m.in. wokół procesów hellenizacji i romanizacji południowej części Półwyspu Apenińskiego, w artykule na temat ośrodków tubylczych południowej Apulii i ich sytuacji wobec rzymskiej ekspansji podjętej w latach 267-218 p.n.e. próbuje przedstawić sytuację prawno-polityczną Messapiów, w jakiej znaleźli się wówczas owi mieszkańcy tej części Italii. Próbę nowego podejścia do problemu prerogatywy imperium Marka Agryppy podjął Paweł Sawiński. Skupia się on na ustaleniu charakteru owego imperium, na którego podstawie Agryppa mógł podejmować działania jako wysłannik cesarza w różnych prowincjach Imperium Romanum.

Wykorzystywaniu ikonografii monetarnej jako środka propagandy służącej interesom danej władzy są poświęcone artykuły dwóch badaczek. I tak Agata Aleksandra Kluczek analizuje ikonografię monet (I wiek p.n.e. - I wiek n.e.), które można zaliczyć do grupy tematycznej restitutio, a Katarzyna Balbuza, przedstawiając swe rozważania na temat działalności tresviri aere argento auro flando feriundo, zastanawia się nad tym, czy urzędnicy odpowiedzialni za emisję monet mieli swobodę w doborze treści monetarnych (legendy, ikonografia), czy nie. Odpowiedź na to pytanie nie jest jednoznaczna, ale wydaje się, że omawiane emisje świadczą o swoistym kompromisie nowego ze starym, swego rodzaju współbrzmieniu na płaszczyźnie idei, co dokonywało się także w wielu dziedzinach ówczesnej rzeczywistości.

Dwa ostatnie artykuły dotyczą zagadnień administracyjnych i politycznych. Karol Kłodziński zajął się funkcjonowaniem administracji rzymskiej w II wieku n.e., a głównie tej jej gałęzi, która wiąże się z administracją prokuratorską. Autor nie koncentruje się jednak na działalności ekwickich prokuratorów, którzy - jak się wydaje - najczęściej byli przedmiotem zainteresowania uczonych ${ }^{12}$, a wyzwoleńców cesarskich, których działalność do dziś nie została w pełni rozpoznana. Na przykładzie karier dwóch liberti Augusti, Aureliusa (?) Saturninusa i Ulpiusa Paeana, Kłodziński pokazuje, że powszechnie dziś przyjmowana teoria „nierównej kolegialności”,

12 Zob. prace zwłaszcza H.-G. Pflauma: Les procurateurs équestres sous le Haut-Empire romain, Paris 1950; Les carriers procuratoriennes équestres sous le Haut-Empire Romain, Paris $1960-1961$. 
tłumacząca równoczesną działalność ekwity i posiadającego ten sam tytuł urzędniczy wyzwoleńca, nie może być przyjmowana bezkrytycznie. Artykuł Krzysztofa Królczyka został poświęcony polityce dynastycznej prowadzonej przez Septymiusza Sewera, panującego w latach 193-211 n.e. Autor pokazał zdecydowane i przemyślane działania Sewera zmierzające do ugruntowania nowej, założonej przez niego dynastii. Taka polityka dynastyczna silnie zespolona z prowadzoną przezeń polityką zewnętrzną, choć nie we wszystkich aspektach ostatecznie zakończona sukcesem, okazała się skuteczna, bo stworzona przez cesarza pochodzącego z Leptis Magna dynastia pozostała u władzy w Imperium Romanum aż do 235 roku n.e.

Problemowa mozaika zamieszczonych w niniejszym tomie „Klio” artykułów pokazuje, że ogólnie sformułowany temat toruńskiej konferencji był swoistym hasłem wywoławczym, który zachęcił specjalistów z różnych obszarów badań nad przeszłością Rzymu do podzielenia się w gronie znawców własnymi obserwacjami i poddania pod dyskusję wniosków płynących z ich spostrzeżeń, nierzadko wstępnych lub mających aspekt rekonesansu naukowego, albo też zmierzających do swoistej weryfikacji pewnych stwierdzeń już od dawna w nauce zakorzenionych. Wszystko to pozwala organizatorom toruńskiej konferencji z pewną dozą optymizmu myśleć nad nadaniem jej charakteru spotkań cyklicznych. 